\title{
Treatment of Refinery Industry Wastewater Using Ion Exchange \\ Technology and Studies Kinetics and Thermo-dynamic Parameters
}

Dr. Thamer J. Mohammed*, Saif I. Habeeb ${ }^{*}$, Zaydoun K.Kreamid ${ }^{* *}$, Ali A. Ali ${ }^{* *}$

*Department of Chemical Engineering, University of Technology, Baghdad, Iraq.

${ }^{* *}$ Petroleum Research and Development Center, Ministry of Oil.

Corresponding Author Email- thamer_jasim58@yahoo.com,

\section{Abstract}

A batch system has been used for removal of chloride, sulfate and sodium pollutants from wastewater of Daura refinery. The fine grained resin lewatit was used in this study, batch experiments were performed to examine the effects amount of resin and mixing time on the removal efficiency and residual of pollutants. The kinetics and thermodynamics of adsorption were also analyzed. Various thermodynamic parameters such as enthalpy $\left(\Delta \mathrm{H}^{\circ}\right)$, free energy $\left(\Delta \mathrm{G}^{\circ}\right)$ and entropy $\left(\Delta \mathrm{S}^{\circ}\right)$ showed that the adsorption was endothermic, spontaneous and feasible. The removal efficiency of sulfate, chloride and sodium is $(91 \%$, $88 \%, 82 \%)$, respectively. The optimum mixing time is (12min) for sulfate and sodium, and (14 min) for chloride. Sulfate adsorption on lewatit fitted well to the pseudo-second-order kinetic model, but adsorption of chloride and sodium on lewatit behaves to the pseudofirst-order kinetic model.

Keywords: Ion-exchange resin, Adsorption, kinetics, chloride, sulfate, sodium.

$$
\begin{aligned}
& \text { معالجة مياة الصرف الصناعي النفطي باستخدام تكنولوجيا المبادلات الايونية والدراسة الحركية } \\
& \text { والمتضيز ات الثرمود|ينميكية } \\
& \text { ثامر جاسم محمد، سيف اسماعيل حبيب، علي احمد علي، زيدون خلف }
\end{aligned}
$$




$$
\begin{aligned}
& \text { تم الوصول الى أفضل وزن مستخدم ووقت خلط بو اسطة الر اتتجات السالبة لاز الة الكبريتات و الكلوريدات هو } \\
& \text { 0,8 غر ام، } 8 \text { غرام، } 12 \text { دقيقة و } 14 \text { دقيقة عند سرعة خلط ثابتة والبالغة } 200 \text { دورة/دقيقة والدالة الحامضية متعادلة } \\
& \text { لتعطي نسبة الازالة مقدارها 91\% للكبريتات ولتركيز ابتدائي مقدارة } 400 \text { جزء بالمليون، ونسبة أزالة 88\% } \\
& \text { للكلوريدات ولتركيز أبتائي } 350 \text { جزء بالمليون، ونسبة أز الة 82\% للصوديوم ولتركيز أيندائي } 200 \text { جزء بالمليون.. }
\end{aligned}
$$

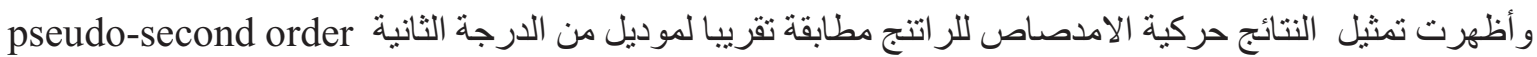
kinetic model بالنسبة لاز الة الكبريتات ومن الدرجة الاولى لاز الة الكلوريدات و الصوديوم.

\section{Introduction}

The advances in technology and industry, large amounts of water are used for industrial activities and consequently significant volumes of wastewaters are generated. Based on the type of industry, various levels of pollutants are deliberately released and discharged into the environment directly (Donald and Herbert, 1979) [6].

Wastewaters released by oil refineries contain large amounts of toxic derivatives such as oil and grease, phenols, sulphides, cyanides, suspended solids, nitrogen compounds as well as heavy metals such as iron, nickel, copper, selenium, zinc, molybdenum, salt (organic and inorganic), etc (Graham, 1959) [8], but Not all salts (contaminants) are toxic or harmful and therefore do not have to be removed to make water safe to drink. Ion exchange is the reversible interchange of ions between a solid ion-exchange medium and a solution. Cations may be exchange for $\mathrm{Na}^{+}$or $\mathrm{H}^{+}$, while anions are exchanged for $\mathrm{OH}^{-}$.

Most exchange media in current use are in a form of soluble synthetic polymer resins, although some naturally occurring minerals such as the green sand and Zeolite are also used (Mat Calf and Eddy, 1981; Hikki, 1999) [11.17]. Hardness, the salts of calcium and magnesium bicarbonate (or chloride \& sulfate) may precipitate out on heating coils and in boilers and cause scale to form add to the salts sodium. Yet they are safe to consume in drinking water. For example higher pressures boilers may require very "pure" or demineralized water (water from which the minerals have been removed) (WQA, 1996) [27]. To remove unwanted ions (dissolved salts) from water, a process called "ion exchange" is most often used.

The important characteristics of ion exchange resin are moisture content and particle size. Water is an essential component of ion exchange resins for many purposes. It has an influence on the porosity and selectivity of the resin, as higher moisture content leads to increased porosity and therefore the active exchange sites are spaced further apart 
(DeSilva, 1999) [5]. The water content of a resin is inversely related to the degree of cross linking. Therefore, a drastic increase in water content is indicative of a reduction in cross linking (Harland and Clive, 1994) [10].

Particle size has two influences on ion exchange processes. The rate of exchange for a resin decreases with increasing particle size due to the lower surface area available for exchange. Head loss through ion exchange beds increases as a result of decreasing particle size. As a result, smaller beads are more likely to fracture (Crittenden. et al, 2005) [4]. The bead size of conventional resins is 300 to $1200 \mu \mathrm{m}$.

On the basis of origin, there are two general types of ion exchange materials, that is, organic and minerallic; the former majority is synthetic polymers available in cationic and anionic forms whereas the latter exists in cation-exchange form only (e.g., zeolites and betonites). Thus, organic ion exchange materials can be cationic, anionic, and combined cationic/anionic (amphoteric) exchangers considering the nature of fixed ion exchange sites (functional groups). Since ion exchangers act in a similar way to conventional acids and bases, the main classes of these materials, that is, cation and anion exchangers, can be further classified depending on the type of the functional group into several types: strongly acidic, strongly basic, weakly acidic, and weakly basic materials (Inamuddin and Mohammad , 2012) [13].

The aim of the present work was to investigate that treatment of wastewater (in Daura refinery) by ion exchange (resin) to removal pollutant ion of sulfate, chloride, sodium and during this treatment, also will be calculating best weight of resin, mixing time, study the effect of temperature on removal efficiency of pollutant, study kinetic of reaction and thermodynamic parameter of ion exchange method.

\section{Theoretical concepts}

\subsection{Ion Exchange Capacity}

Generally, the ion exchange capacity is expressed in terms of total exchange capacity; the capacity is expressed in terms of a wet-volume capacity. The wet-volume capacity depends upon the moisture content of the resin which is dependent upon the functional form of the resin and will vary for a given type of resin. The wet-volume capacity is commonly expressed in milliequivalents per milliliter of resin bed (meq $/ \mathrm{mL})$, although it may also be expressed in terms of kilograins as $\mathrm{CaCO}_{3}$ per cubic foot $\left(\mathrm{kg} / f t^{3}\right)$ 
of resin which depends on the quantity of functional groups in the resin bead.

\subsection{Selectivity}

The selectivity of an ion exchange resin indicates the affinity or preference towards certain anions in terms of anion exchange and cations for cation exchange. . Selectivity depends on various properties of the resin bead such as moisture content and functional group (DeSilva, 1999; Crittenden et al, 2005) [4, 5]. In general, the magnitude of valence and the atomic number of the ion impact the selectivity of a resin. Ion exchange resins have greater affinity or selectivity for ions with increasing charge. In cases where multiple ions carry the same charge, selectivity is based on the atomic number of the ion, where a higher atomic number is more selective (DeSilva, 1999; Harland and Clive, 1994) $[5,10]$. The selectivity typically increases with increasing charge on the exchanging cation in the order:

$$
\mathrm{Li}^{+}<\mathrm{H}^{+}<\mathrm{Na}^{+}<\mathrm{K}^{+}<\mathrm{Cs}^{+}<\mathrm{Rb}^{+}<\mathrm{Ag}^{+}<\mathrm{Be}^{+2}<\mathrm{Mg}^{+2}<\mathrm{Cu}^{+2}<\mathrm{Ni}^{+2}<\mathrm{Co}^{+2}<
$$
$\mathrm{Ca}^{+2}<\mathrm{Sr}^{+2}<\mathrm{Ba}^{+2}<\mathrm{Ce}^{+3}<\mathrm{La}^{+3}<\mathrm{Th}^{+4}$

For anions, a typical series of selectivity is as follows:

$$
\begin{aligned}
\mathrm{F}^{-} \approx \mathrm{OH}^{-}< & \mathrm{HCO}_{3}^{-}<\mathrm{CH}_{3} \mathrm{COO}^{-}<\mathrm{CL}^{-}<\mathrm{HSO}_{3}^{-}<\mathrm{Br}^{-}<\mathrm{CrO}_{4}^{-2}<\mathrm{NO}_{3}^{-}<\mathrm{SCN}^{-} \\
& <\mathrm{I}^{-}<\mathrm{CLO}_{4}^{-}<\mathrm{C}_{2} \mathrm{O}_{4}^{-2}<\mathrm{SO}_{4}^{-2}
\end{aligned}
$$

\subsection{Distribution Coefficient}

The distribution coefficient is the concentration of an ion in the exchanger divided by its concentration in the solution at the equilibrium state. The distribution coefficient $k_{d}$ is determined by the formula (Strelowand and Baxter, 1969) [22]:

$$
k_{d}=\frac{\text { amount on resin }}{\text { amount in the solution }} \times \frac{m L \text { of solution }}{\text { gm of dry resin }}
$$

The value of $k_{d}$ can range from near unity to relatively large powers of ten. $k_{d}$ is a coefficient not a constant and its value depends on several factors. First, it is depend on the concentration of the ion to be separated. Second, $\mathrm{k}_{\mathrm{d}}$ is dependent on the concentration of other ions with the same charge present in the solution; the presence of other competing ions decreases the binding of the target ion to the exchanger. 


\subsection{Kinetics of Adsorption}

\subsubsection{Pseudo-First Order Reaction Kinetic}

Simple linear equation for Pseudo-first order reaction kinetic is given below (Sharma and Bhattacharyya, 2004) [21]:

$$
\ln \left(q_{e}-q_{t}\right)=\ln q_{e}-k_{1} t
$$

Where:

$k_{1}=$ the rate constant of the first-order adsorption ( $\left.1 / \mathrm{min}\right)$.

$q_{t}=$ the amount of ion adsorbed at time $t(\mathrm{mg} / \mathrm{g})$.

$q_{e}=$ the amount of ion adsorbed at saturation $(\mathrm{mg} / \mathrm{g})$.

Plot of $\ln \left(q_{e}-q_{t}\right)$ versus $t$ allows calculation of the rate constant $k_{l}$ and $q_{e}$.

\subsubsection{Pseudo-Second Order Reaction Kinetic}

Pseudo-second order reaction kinetic can be expressed as (Mckay and Ho, 1998) [18]:

$$
\frac{\mathrm{t}}{\mathrm{q}_{\mathrm{t}}}=\frac{1}{\mathrm{k}_{2} \mathrm{q}_{\mathrm{e}}^{2}}+\frac{\mathrm{t}}{\mathrm{q}_{\mathrm{e}}}
$$

Where:

$k_{2}=$ pseudo-second order rate constant ( $\left.\mathrm{g} / \mathrm{mg} \min \right)$.

Similar to pseudo-first order reaction kinetic, $q_{e}$ and $k_{2}$ can be determined from the slope and intercepts of plot $t / q_{t}$ versus $t$.

One of studies of water and wastewater treatment is (Brown et al 2002) [2] use of a novel ion exchange process, it has made it possible to utilize either strong or weak acid cation resin to soften produced waters at TDS levels up to $7000 \mathrm{mg} / \mathrm{L}$ to levels of residual hardness below $0.1 \mathrm{mg} / \mathrm{L}$. By utilizing large dosages of high purity brine it is possible to eliminate the use of acid and caustic, even for regeneration of WAC resins.

\section{Experimental}

\subsection{Materials}

In this study, ion exchange technical used chemicals material resin [strong basic anion Lewatit (mp 500) and strong acid cation Lewatit (S108)]. Resin material (cation and anion) is typically porous, providing a high surface area. The trapping of ions occurs with the accompanying releasing of other ions. 


\subsection{Apparatus and methods}

Many apparatus that using in this present work such as laboratory shaker model (Heidolph Unimax 1010), UV-1100 Spectrophotometer, Chromatography column and Ionselective. The more details was shown in (Saif, 2017) [20]

\subsection{Methods}

Put ( 100 ) ml volume of wastewater sample in beaker and add different weights in grams of the resin material (such as cation) in beaker, and beaker put on the shaker apparatus ,shaker is operated at a constant speed (200rpm) and also of different times and filtrate the mixture and the filtrate is taken for analysis. And the details procedure was shown in ( Saif, 2017) [20].

\section{Results and discussion}

\subsection{Effect of Weight Resin on Removal Efficiency of Chloride, Sulfate and Sodium}

The resin amount is one of the important parameters used to obtain the quantitative ion exchange. The dependence of ion exchange on resin amount was studied by varying the quantity of strong basic anion Lewatit (mp 500) $(0.1-0.8 \mathrm{gm})$ in $100 \mathrm{~mL}$ of Sulfate solution, and (1 - $8 \mathrm{gm})$ in $100 \mathrm{ml}$ of Chloride solution, and strong acid cation Lewatit (S108) (0.5-4 gm) in $100 \mathrm{~mL}$ of sodium solution,at $\mathrm{pH}$ (7) because this types of resin operates of wide range of $\mathrm{pH}$ from (1 to 14$)$, and contact times (15min for anion, $10 \mathrm{~min}$ for cation). The shaker speed of $200 \mathrm{rpm}$ which remained constant at temperature was maintained at room temperature. It is apparent that the removal efficiency of sulfate, chloride and sodium ions increases with higher resin dosages as shown in Figs the removal efficiency of an adsorbent (as ion exchange) increases with increase in adsorbent dose (resin), due to the availability of an extra vacant site of resin to be occupied by pollutants (Xing et al, 2011). As seen from the Fig.(1) the optimum resin amounts are $0.7 \mathrm{~g}$ and $0.8 \mathrm{~g}$ in $100 \mathrm{~mL}$ of sulfate solution $\left(C_{i}=400 \mathrm{ppm}\right)$ given $[\mathrm{R} \%=91$, residual $=37 \mathrm{ppm}]$ and $0.8 \mathrm{~g}$ in $100 \mathrm{~mL}$ of sulfate solution $\left(C_{i}=800 \mathrm{ppm}\right)$ given $[\mathrm{R} \%=76$, residual=194ppm]. In Fig. (2) was shown the chloride with $\left(C_{i}=350 \mathrm{ppm}\right)$, the removal efficiency achieved is $[\mathrm{R} \%=88$, residual $=42 \mathrm{ppm}]$ at dose of $(8 \mathrm{gm})$ and $[\mathrm{R} \%=67$, residual $=212 \mathrm{ppm}]$ at dose $(8 \mathrm{gm})$ for $\left(C_{i}=650 \mathrm{ppm}\right)$. And achieve optimum amount of resin for sodium $\left(C_{i}=200 \mathrm{ppm}\right)$ at $(3.5-4$ $\mathrm{gm})$ this amount given removal efficiency $[\mathrm{R} \%=80-82$, residual $=40-36 \mathrm{ppm}]$ that shown in Fig. (3).This result is in agreement with some results published by (Ghaly and Verma, 
2008) [7] that studied removal of sodium salt and found the sodium salt removal efficiency is $(75.3 \%)$.) Caputo and Pepe, 2007) reported reductions in contaminants of up to $99.99 \%$ using a series of zeolite columns depending upon type of zeolite, valence of salt cation and salt concentration.

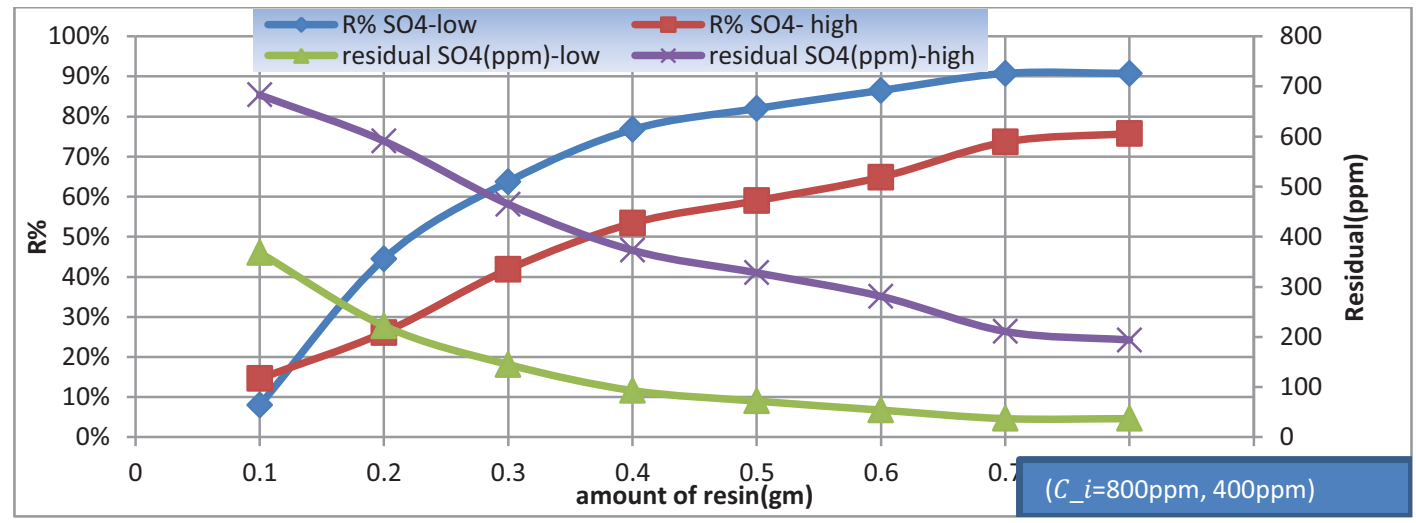

Fig. (1) Effect of dose resin on the removal efficiency and residual of sulfate.

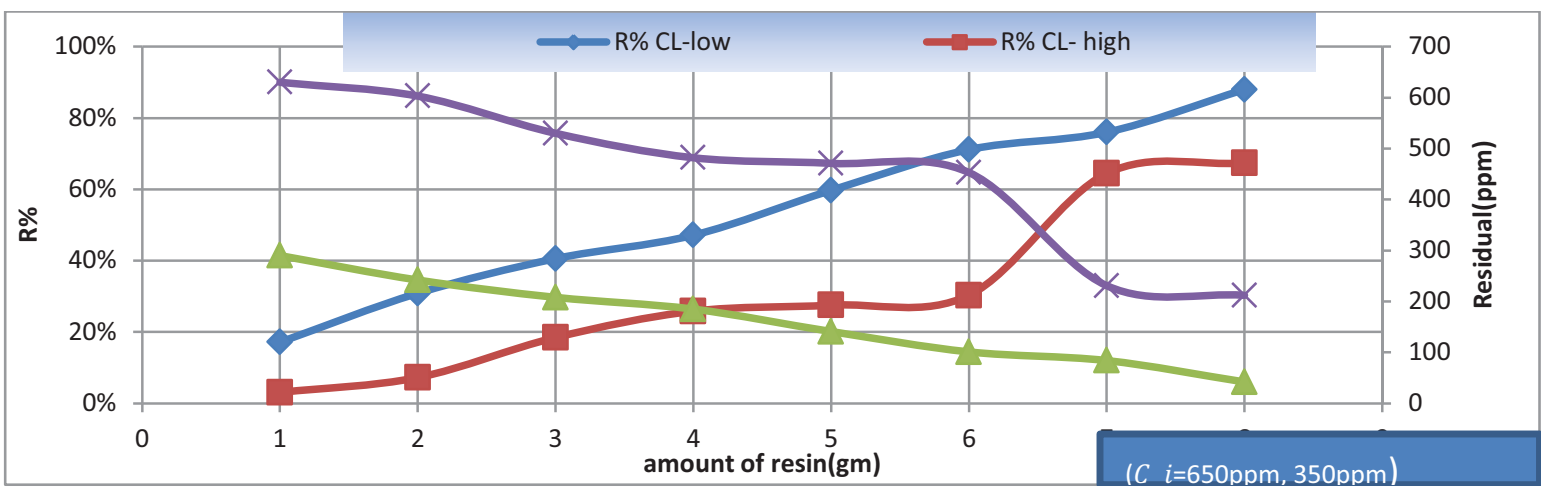

Fig. (2) Effect of dose resin on the removal efficiency and residual of chloride.

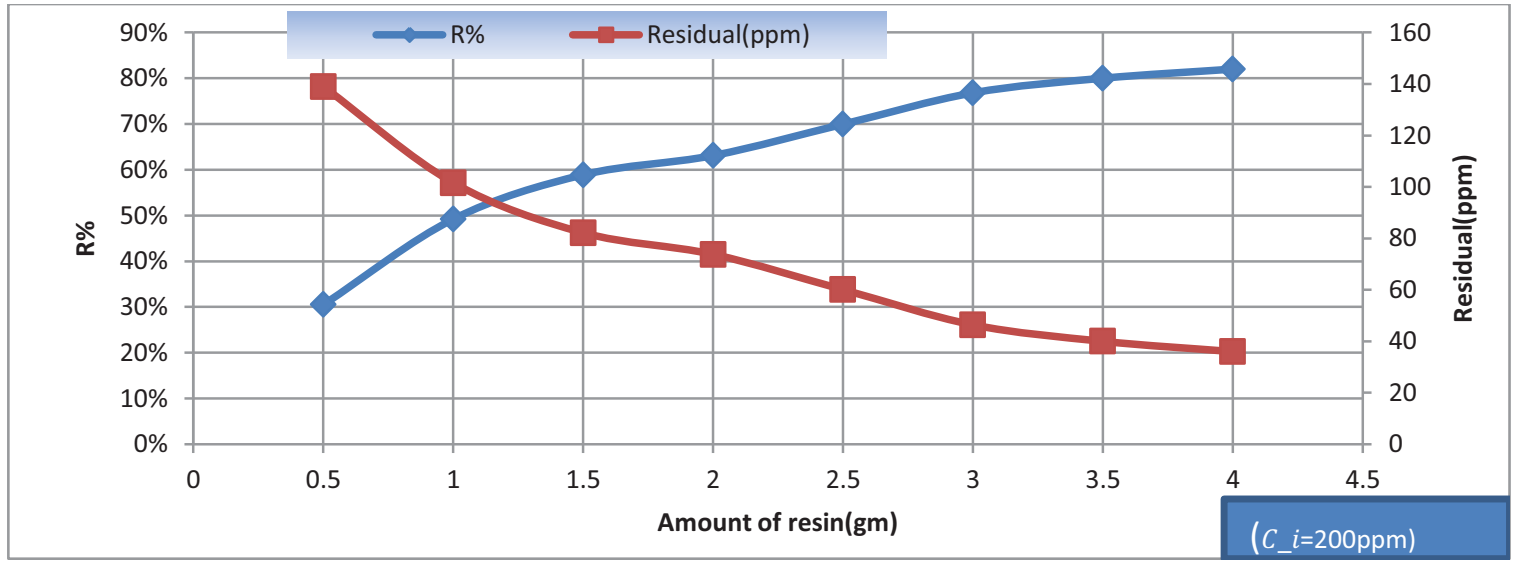

Fig. (3) Effect of dose resin on the removal efficiency and residual of sodium. 


\subsection{Effect of Mix Time on Removal Efficiency of Chloride, Sulfate and Sodium}

The effect of contact time on the ion exchange of $\mathrm{SO}_{4}^{-2}, \mathrm{CL}^{-1}$ and $\mathrm{Na}^{+1}$ by strong basic anion Lewatit ( $\mathrm{mp} \mathrm{500)}$ ) and strong acid cation Lewatit (S108) exchange resin was studied by taking $(0.1,2,0.5) \mathrm{gm}$ of resin with $100 \mathrm{~mL}$ of $\mathrm{SO}_{4}^{-2}, \mathrm{CL}^{-1}$ and $\mathrm{Na}^{+1}$ solution, respectively, in different flasks. The flasks were shaken for (2-16 minutes), the $\mathrm{pH}$ of wastewater before treatment was (7). The shaker speed of $200 \mathrm{rpm}$ remained constant at temperature was maintained at room temperature. It is apparent that the removal efficiency of sulfate and chloride ions increased with mixing time as shown in Figs. (4-6). Equilibrium time is one of the parameters for economical wastewater treatment (Kadirvelu et al, 2003) [15]. As seen from Fig. (4) the optimum mixing time is (12min) for sulfate solution $\left(\mathrm{C}_{\mathrm{i}}=400 \mathrm{ppm}\right)$ given $[\mathrm{R} \%=25$, residual $=300 \mathrm{ppm}]$ and sulfate solution $\left(\mathrm{C}_{\mathrm{i}}=800 \mathrm{ppm}\right)$ given $[\mathrm{R} \%=19$, residual=650ppm]. In Fig. (5) was shown the chloride with $\left(C_{i}=350 \mathrm{ppm}\right)$, the removal efficiency achieved is $[\mathrm{R} \%=23$, residual $=270 \mathrm{ppm}]$ at time $(14 \mathrm{~min})$ and $[\mathrm{R} \%=18$, residual $=530 \mathrm{ppm}]$ at time $(14 \mathrm{~min})$ for $\left(\mathrm{C}_{\mathrm{i}}=650 \mathrm{ppm}\right)$. The effect of time mixing on removal of sodium is remain constant after $(12 \mathrm{~min})$ of mixing to given $[\mathrm{R} \%=45$, residual $=111 \mathrm{ppm}]$ this resulted was shown in Fig. (6).

The percentage of ions adsorbed increased rapidly during the first few minutes, and then increased slowly until the equilibrium state is reached. It has been revealed that adsorption is higher at the beginning of adsorption process due to the larger surface area of the adsorbent being available at beginning for the adsorption of ion and exchange. As the surface adsorption sites become exhausted, the uptake rate is controlled by the rate at which the adsorbate is transported from the exterior to the interior sites of the adsorbent particles. These notes were indicated by (Acksu, 2001) [1].

The fast adsorption at lower level was probably due to the initial concentration gradient between the adsorbate in solution and the number of vacant sites available on the surface at the beginning. The progressive increase in adsorption and consequently the attainment of equilibrium was due to limited mass transfer of the adsorbate molecules from the bulk liquid to the external surface of the adsorbents as reported by (Acksu, 2001), and the initial concentration gradient is between the adsorbate in solution and the number of vacant sites available on the adsorbent surface at the beginning. 


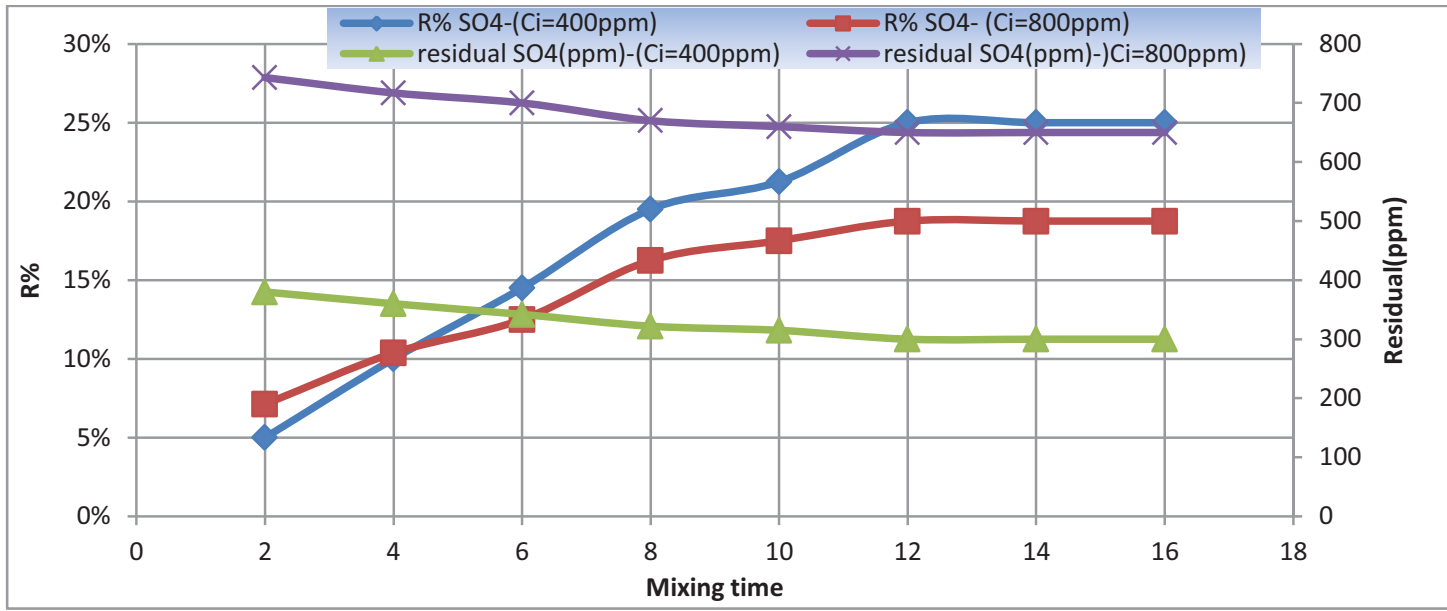

Fig. (4) Effect of mixing time on the removal efficiency and residual of sulfate.

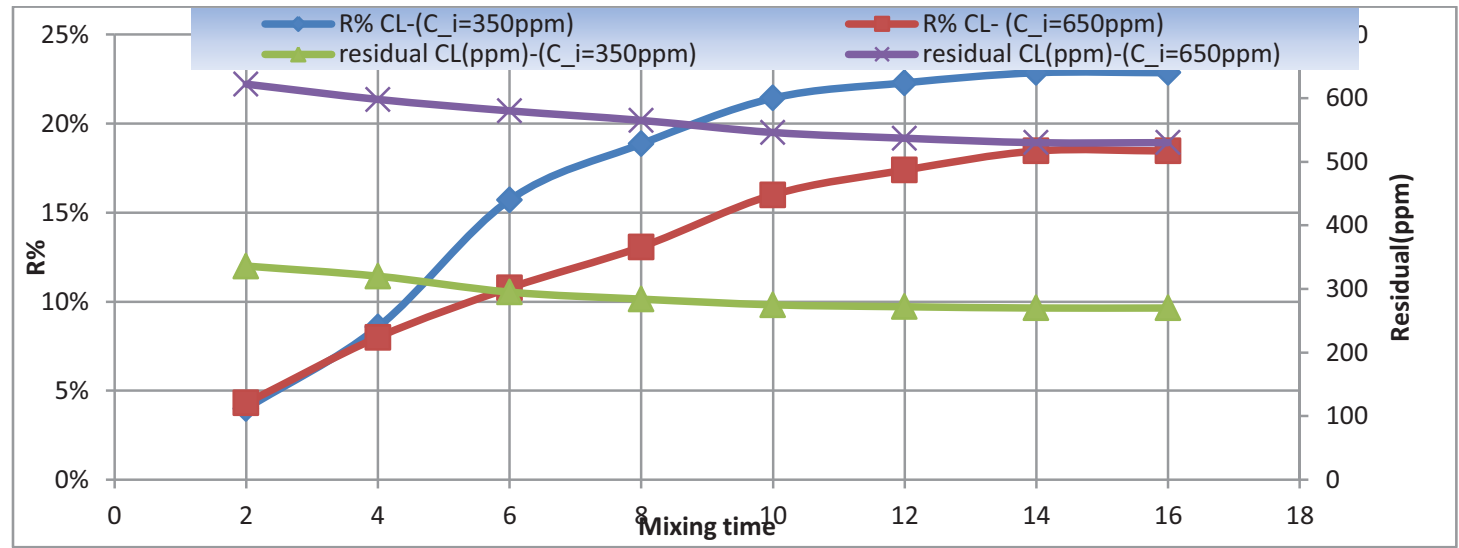

Fig. (5) Effect of mixing time on the removal efficiency and residual of Chloride.

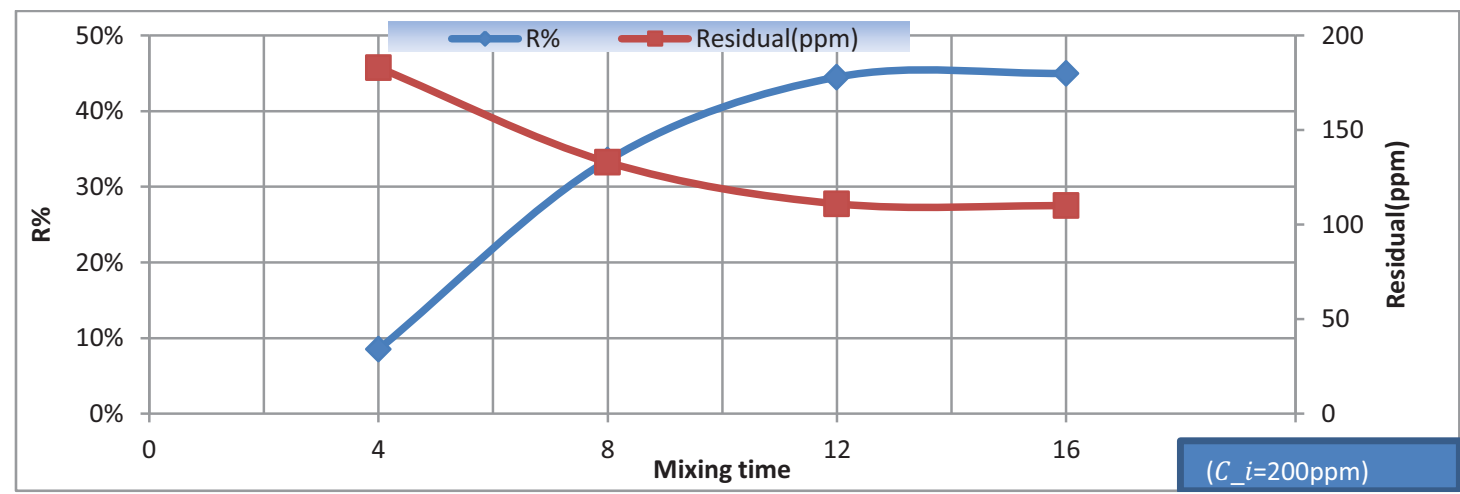

Fig. (6) Effect of mixing time on the removal efficiency and residual of sodium. 


\subsection{Effect of Temperature}

In order to investigate the effect of temperature on ion adsorption onto Lewatit (MP 500) and cation Lewatit (S108) in a single component systems, experiments were carried out with initial concentrations of $\mathrm{SO}_{4}^{-2}, \mathrm{Cl}^{-1}$ and $\mathrm{Na}^{+1}$ solution $(400,350,200$ $\mathrm{ppm})$, and $(0.2,5,0.5) \mathrm{gm}$ resin weight, respectively, at 10 minutes mixing time, $\mathrm{pH} 7$ and using three different temperatures $\left(25,40\right.$ and $\left.60^{\circ} \mathrm{C}\right)$ and a constant stirring speed of 200 rpm. The results show a decrease in ion removal by increasing the temperature of the system Fig. (7)

As seen from the figure the removal efficiency of sulfate decreased from $[\mathrm{R} \%=60$ to 50$]$, chloride from $[\mathrm{R} \%=35$ to 21$]$, and sodium from $[\mathrm{R} \%=68$ to 62$]$ with increasing temperature from 25 to $60^{\circ} \mathrm{C}$ at $\mathrm{pH}=7$.

The results show that the removal of chloride is greater than the sulfate and sodium. The sequence of removal is therefore $\mathrm{Cl}<\mathrm{SO} 4<\mathrm{Na}$.

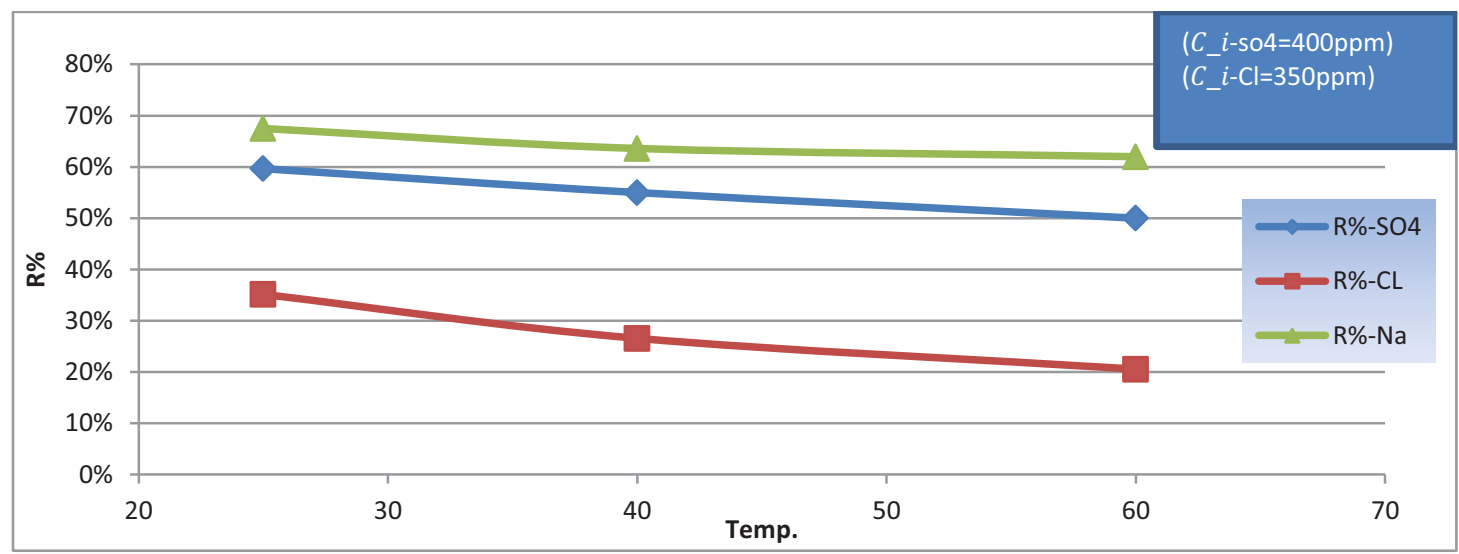

Fig. (7) Effect of temperature on the removal efficiency of sulfate, chloride and sodium.

\subsection{Ion Exchange Kinetic}

Kinetics of adsorption describing the solute uptake rate, which in turn governs the residence time of adsorption reaction and it is one of the important characteristics defining the efficiency of adsorption (Zhihui et al., 2009) [27].

In this section, pseudo-first-order equation and pseudo-second order equation were used to test the experimental data of signal component system.

Plotting $\ln \left(q_{e^{-}} q_{t}\right)$ against (t) in Fig. (8) Provided pseudo-first-order adsorption rate constant $\left(k_{1}\right)$ and $\left(q_{e}\right)$ values from the slope and intercept and listed in Table (1) 


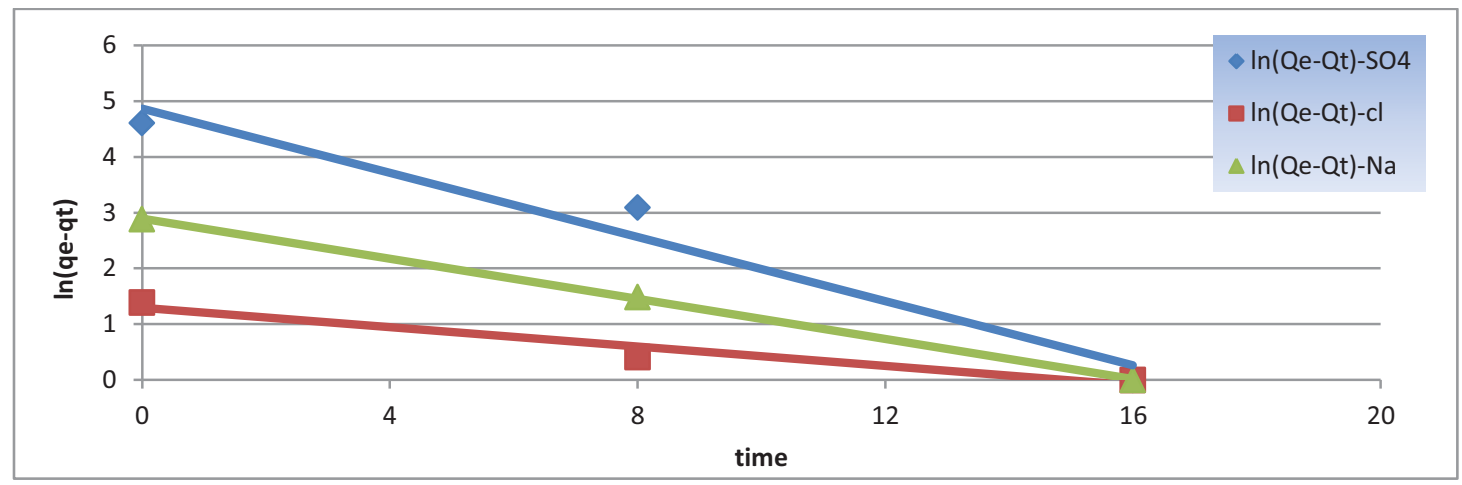

Fig. (8) Pseudo-first-order for ion exchange of sulfate, chloride, and sodium.

Figure (9) show plotting of $t / q_{t}$ against $t$, from this figure pseudo-secondorder adsorption rate constant $k_{2}$ and $q_{e}$ values are obtained from the slope and intercept. Table (1) show a comparison of adsorption rate constants, experimental and calculated $q_{e}$ values for the pseudo-first and second-order reaction kinetics.

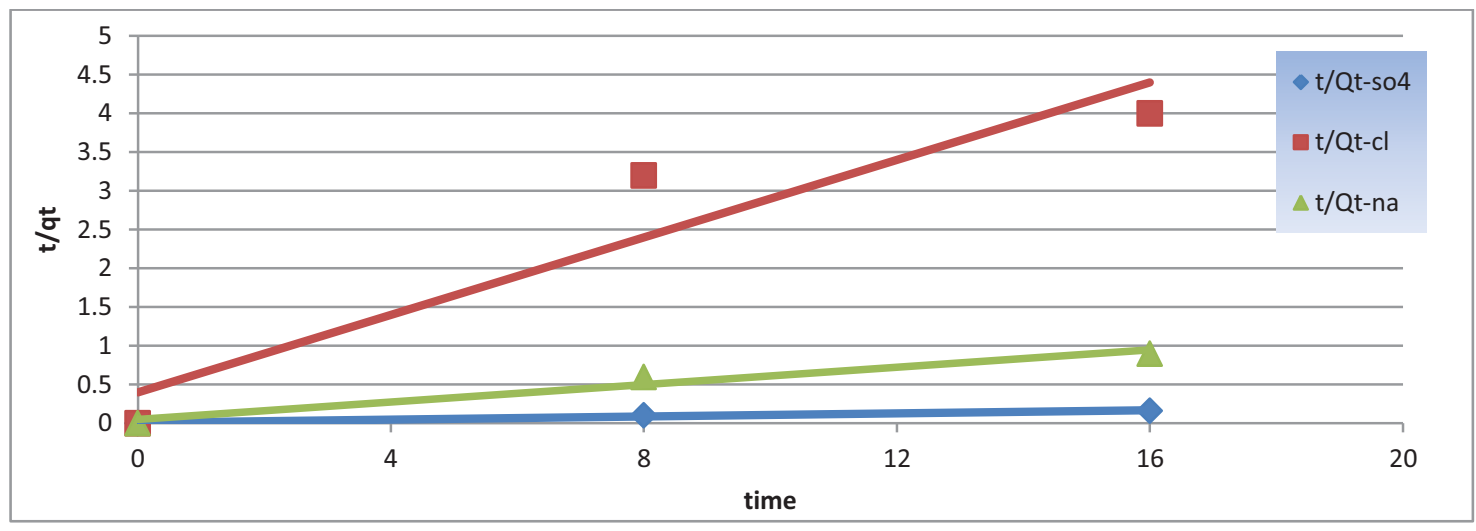

Fig. (9) Pseudo-second-order for ion exchange of sulfate, chloride, and sodium.

The values of correlation coefficient $\left(\mathrm{R}^{2}\right)$ and $\left(q_{e}\right.$ calculated $)$ indicate a better fit of pseudo-second-order model with the experimental data compared to pseudo-first-order model for sulfate, but for chloride and sodium the values of correlation coefficient $\left(\mathrm{R}^{2}\right)$ indicate a better fit pseudo-first-order model. And the regression coefficients are over 0.945. The values of $q_{e}$ calculated from the second order kinetic model agreed well with the experimental values, Therefore, the second-order model can be applied for the entire adsorption process respect to sulfate and the first-order model can be applied for the entire adsorption process respect to chloride and sodium. 
Table (1) Comparison of adsorption rate constants, experimental and calculated $q_{e}$ values for the pseudo-first- and-second-order reaction kinetics for removal of sulfate, chloride and sodium.

\begin{tabular}{|c|c|c|c|c|c|c|c|}
\hline Ion & $\boldsymbol{q}_{\boldsymbol{e}}$ & \multicolumn{3}{|c|}{ Pseudo-first-order } & \multicolumn{3}{c|}{ Pseudo-second-order } \\
\cline { 3 - 8 } & $\begin{array}{c}\text { experim } \\
\text { ental }\end{array}$ & $\boldsymbol{k}_{\boldsymbol{1}}$ & $\begin{array}{c}\boldsymbol{q}_{\boldsymbol{e}} \\
\text { calculated }\end{array}$ & $\boldsymbol{R}^{2}$ & $\boldsymbol{k}_{\mathbf{2}}$ & $\begin{array}{c}\boldsymbol{q}_{\boldsymbol{e}} \\
\text { calculated }\end{array}$ & $\boldsymbol{R}^{2}$ \\
\hline $\mathrm{SO}_{4}$ & 100 & 0.287 & 130 & 0.9624 & 0.013 & 100 & 0.9742 \\
\hline $\mathrm{CL}$ & 4 & 0.0866 & 3.63 & 0.9457 & 0.156 & 4 & 0.8929 \\
\hline $\mathrm{Na}$ & 17.8 & 0.1799 & 18.05 & 0.9997 & 0.064 & 17.79 & 0.9653 \\
\hline
\end{tabular}

\subsection{Thermodynamic Study}

The amounts of sorption of single ions by lewatit were carried out at temperatures of $25^{\circ} \mathrm{C}, 40^{\circ} \mathrm{C}$ and $60^{\circ} \mathrm{C}$. The thermo-dynamic parameters were calculated for this system by using the following Eq. (4) (Khan et al., 1995) [16]:

$$
\ln K_{D}=\left(\frac{\Delta S^{\circ}}{R}\right)-\left(\frac{\Delta H^{\circ}}{R T}\right)
$$

Where:

$\mathrm{K}_{\mathrm{d}}=$ distribution coefficient $(\mathrm{mL} / \mathrm{g})$.

$\Delta H=$ enthalpy $(\mathrm{kJ} / \mathrm{mol})$.

$\Delta S=\operatorname{entropy}(\mathrm{J} / \mathrm{mol} \mathrm{K})$.

$T=$ temperature $(\mathrm{K})$.

$R=$ gas constant $(8.314 \mathrm{~J} / \mathrm{mol} \mathrm{K})$.

The values of enthalpy and entropy were obtained from the slope and intercept of $\ln K_{d}$ versus 1000/T (Fig. 10).

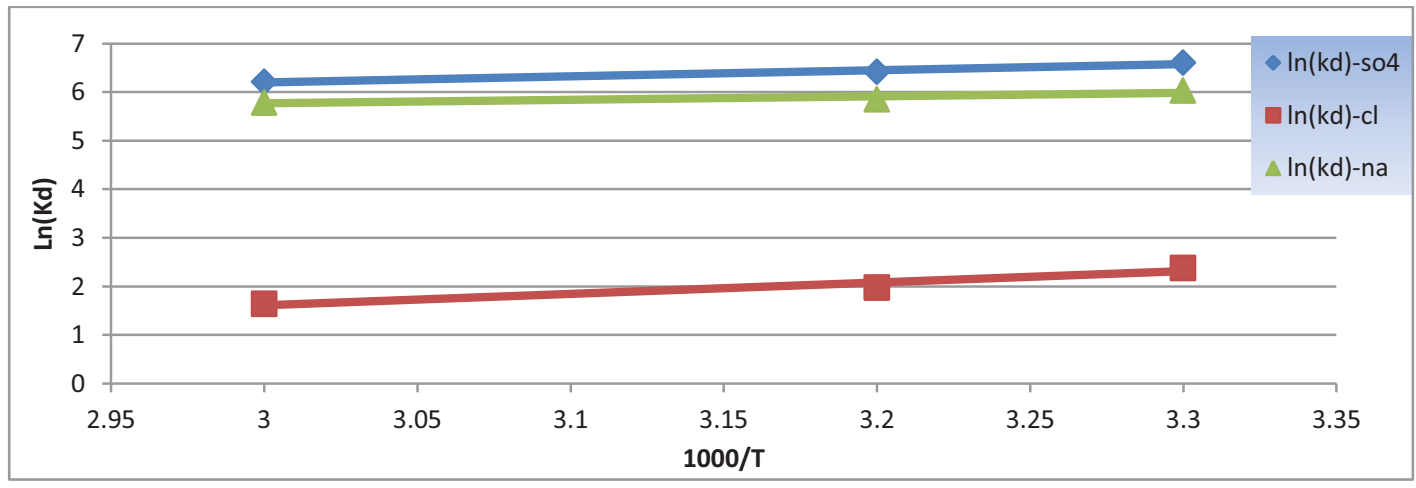

Fig. (10) Distribution coefficient versus 1000/Temperature for single component systems. 
In Table (2) summarizes the distribution coefficients from a series of batch experiments at different temperatures. Gibbs free energy $(\Delta \mathrm{G})$ was calculated using the well-known Eq. (5) (Khan et al., 1995) [16]:

$$
\Delta G=\Delta H-T \Delta S
$$

The values of the thermodynamic parameters for the sorption of ions on lewatit are given in Table (3). Negative values of $\Delta H$ show exothermic nature of the sorption exchange process. Probably some energy emits from the resin as it leaves the hydration sphere to undergo ion exchange with the ion exchange material.

$\Delta G$ depends on several factors such as temperature, heat consumed and released for removal of $\left(\mathrm{H}^{+}, \mathrm{OH}^{-}\right)$and intake of the incoming (cation, anion) in terms of hydration and dehydration as well as the size of the hydrated ionic radii of the (cation, anion). Negative $\Delta G$ values indicate feasibility and spontaneous nature of the sorption process and attainment of a more stable energy level after ion exchange of metal ions (Tagami et al,2001; Zhou et al,2011) [23,28]. The value of $\Delta G$ for these processes becomes less negative with increasing temperature (for chloride), which shows that sorption is less favored at high temperatures. The values of $A G$ ” become more negative with increasing temperature (for sulfate and sodium) which indicates the spontaneity of the process; it further shows that the sorption is favored at higher temperatures.

The entropy reflects changes in hydration sphere of exchanging cation which occurs during the ion exchange process. The $\mathrm{SO} 4$ and $\mathrm{Na}$ ions exhibit positive $\Delta \mathrm{S}$ values which indicate the higher randomness of ion near the adsorbent surface due to ion exchange and reflected the affinity of the adsorbent, but the $\mathrm{Cl}$ ions exhibit negative value of $\Delta \mathrm{S}$ which indicate the higher uniform of ion near the adsorbent surface and the sorbet ions are stable on the solid surface. Association, fixation or immobilization of chloride ions as a result of adsorption is attributed to a decrease in the degree of freedom of adsorbate ions which gives rise to a negative entropy change. 
Table (2) Distribution coefficients of sulfate, chloride and sodium at different temperature.

\begin{tabular}{|l|l|l|l|l|}
\hline \multirow{2}{*}{ Ion } & \multicolumn{4}{|c|}{$\mathrm{Kd}$} \\
\cline { 2 - 5 } & $298^{\circ} \mathrm{K}$ & $313^{\circ} \mathrm{K}$ & $333^{\circ} \mathrm{K}$ & $R^{2}$ \\
\hline $\mathrm{SO}_{4}$ & 739 & 611 & 500 & 0.9698 \\
\hline $\mathrm{CL}$ & 10.8 & 7.2 & 5.2 & 0.9415 \\
\hline $\mathrm{Na}$ & 415 & 349 & 326 & 0.8231 \\
\hline
\end{tabular}

Table (3) Thermodynamic parameters for the adsorption of ions on resin.

\begin{tabular}{|l|l|l|l|l|l|}
\hline \multirow{2}{*}{ Ion } & $\Delta H$ & $\Delta S \quad(\mathrm{~J} / \mathrm{mol}$ & $\Delta G(\mathrm{~kJ} / \mathrm{mol})$ & \\
\cline { 4 - 6 } & $(\mathrm{kJ} / \mathrm{mol})$ & $\mathrm{K})$ & $298 \mathrm{~K}$ & $313 \mathrm{~K}$ & $333^{\circ} \mathrm{K}$ \\
\hline $\mathrm{SO}_{4}$ & -10.47 & 20.1 & -16.4 & -16.7 & -17.1 \\
\hline $\mathrm{CL}$ & -19.52 & -45.1 & -6 & -5.4 & -4.5 \\
\hline $\mathrm{Na}$ & -6.14 & 29.5 & -14.9 & -15.3 & -15.9 \\
\hline
\end{tabular}

\section{Conclusions}

1. When the amount of resin was increasing the final concentration was decreasing and the removal of efficiency was increasing.

2. The highest efficiency was $91 \%$ when anion resin was used and the mix time is 12 min at neutral $\mathrm{pH}$.

3. The selectivity increases generally with higher valence charge.

4. The actual capacity of resin was in safety lime of the theoretical capacity.

5. The adsorption process was endothermic, spontaneous and feasible.

6. Sulfate adsorption on lewatit fitted well to the pseudo-second-order kinetic model, but adsorption of chloride and sodium on lewatit behaves to the pseudo-first-order kinetic model 


\section{References}

1. Acksu, Z., (2001), "Equilibrium and kinetic Modeling of Cadmium (II) Biosorption by C. Vulgaris in Batch System", effect of temperature. Separation and Purification Technology.

2. Brown C.J., Russer A., Sheedy M., (2002). "A New Ion Exchange Process for Softening High TDS Produced Water", the SPE International Thermal Operations and Heavy Oil Symposium and International Horizontal Well Technology Conference held in Calgary, Alberta, Canada, 4-7 November .

3. Caputo, D. and F. Pepe, (2007)." Experiments and data processing of ion exchange equilibria involving Italian natural zeolites: a review.Microporous and Mesoporous Mater". 105 (3): 222-231.

4. Crittenden. J.C., Rhodes Trussell, R., Hand, D.W., Howe, K.J. and Tchobanoglous, G. (2005)." Water Treatment: Principles and Design", Chapter 9. New Jersey: Wiley and Sons, Inc.

5. DeSilva, F.J (1999) "Essentials of Ion Exchange. Proceedings": 25th Annual Water Quality Association (WQA) Conference, Lisle, IL.

6. Donald W.S.,and Herbert E.K.(1979)"Wastewater Treatment" Prentice-Hall, Inc.

7. Ghaly and Verma,(2008) "Desalination of Saline Sludges Using Ion-Exchange Column with Zeolite".American Journal of Environmental Sciences 4 (4): 388-396.

8. Graham D., (1959). "Chem. Eng. Pro. Symposiur Series"; Vol. 155

9. Gupta, V. K. and Sharma, S. (2003)." Removal of Zinc from Aqueous Solutions Using Bagasse Fly Ash a Low Cost Adsorbent", Ind. Eng. Chem. Res. Vol. 42, pp. 6619-6624.

10. Harland, Clive E. (1994)."Ion Exchange: Theory and Practice". Cambridge, UK: The Royal Society of Chemistry. (2nd Ed.).

11. Hikki L., (1999). "Removal of Harmful Metals from Metal Plant Wastewaters Using Selection Exchangers", Report series in radiochemistry, University of Helsinki

12. Howe et al. (2012)." Principles of Water Treatment", capter 10, Adsorption and Ion Exchange, United States of America, by John Wiley \& Sons.

13. Inamuddin and Mohammad Luqman, (2012)."Ion Exchange Technology I Theory and Materials", Springer Dordrecht Heidelberg New York London.

14. J. W. Clark, W. Viessman and M. J. Hammer, (1971). "Water Supply and Pollution Control", International Textbook Company, Scrontes, PA.

15. Kadirvelu, K., Thamaraiselvi, K. and Namasivayam, C., (2003). "Removal of heavy metals 
from industrial wastewaters by adsorption onto activated carbon prepared from an agricultural solid waste", Bioresource Technology.

16. Khan, S.A., Rehman, R., Khan, M.A., (1995). "Adsorption of chromium (II), chromium (VI) and silver (I) on bentonite", Waste Mange. Vol. 15, PP. 271-282.

17. Mat Calf and Eddy, (1981). "Wastewater Engineering: Treatment, Disposal reuse", Second Edition, university of California, Davis.

18. Mckay, Y. S. and Ho, G., (1998)." Sorption of Dye from Aqueous Solution by Peat", J. Chem. Eng. Vol. 70, pp. 115-124.

19. Midland Refineries Company/ Dora refinery, (2015), Baghdad, Iraq.

20. Saif Ismail Habeeb ,(2017). "Treatment of AL- Daura Refinery Wastewater Using Different Tertiary Methods", M.Sc. Thesis, University of Technology.

21. Sharma, A. and Bhattacharyya, K.G., (2004). "Adsorption of chromium (VI) on Azadirachta Indica (Neem) leaf powder", Adsorption, Vol. 10, PP. 327-338.

22. Strelowand, F.E.W., Baxter, C., (1969). "Separation of Tetravalent Rare Earths and Scandium from Aluminum, Iron (III), Titanium(IV), and other Elements by CationExchange Chromatography in Hydrochloric Acid-Ethanol", Talanta, Vol. 16, pp. 1145-1155

23. Tagami, L., Andreo O. A., Sousa-Aguiar, E. F., Arroyo, P. A., Simoes, M. A., (2001)."NaY and CrY Zeolite Ion Exchange. Thermodynamics", Acta Scientiarum Maringa, 23, 13511357.

24. Veli, S. and Ozturk, T., (2005). "Kinetic and Modeling of Adsorption of Reactive Azo Dye on Powdered Activated Carbon and Pumice", Fresenius Environ. Bull, Vol. 14, pp. 347353.

25. Water Quality Association, Deionization Basics, (1996). WQA, Lisle, IL.

26. Xing, S., Zhao, M. and Ma, Z., (2011). "Removal of heavy metal ions from aqueous solution using red loess as an adsorbent", Journal of Environmental Sciences.

27. Zhihui Yu, Tao Qi, Jingkui Qu, Lina Wang, Jinglong Chu, (2009). "Removal of Ca (II) and Mg (II) from Potassium Chromate Solution on Amberlite IRC784 Synthetic Resin by Ion Exchange", Journal of Hazardous Materials.

28. Zhou, X., Xue. X., Jiang, W., (2011). "Study of Adsorption of Heavy Metal Ion in Metallurgical Wastewater by Sepiolite", International Conference Environmental Science and Development IPCBEE, vol. 4. 